OPEN ACCESS

Edited by:

María Poca,

CONICET San Luis Institute of Applied Mathematics (IMASL), Argentina

Reviewed by: Seyed Mohammad Moein Sadeghi,

Transilvania University of Brașov, Romania

John T. Van Stan, Cleveland State University, United States

${ }^{*}$ Correspondence: Cristián Frêne cfrene@bio.puc.c

Specialty section: This article was submitted to Forest Hydrology,

a section of the journal Frontiers in Forests and Global

Change

Received: 23 September 2021 Accepted: 20 December 2021

Published: 11 January 2022

Citation:

Frêne C, Núñez-Ávila M, Castro B and Armesto JJ (2022) Seasonal

Partitioning of Rainfall in Second-Growth Evergreen Temperate Rainforests in Chiloe Island, Southern Chile.

Front. For. Glob. Change 4:781663. doi: 10.3389/ffgc.2021.781663

\section{Seasonal Partitioning of Rainfall in Second-Growth Evergreen Temperate Rainforests in Chiloé Island, Southern Chile}

\author{
Cristián Frêne ${ }^{1 *}$, Mariela Núñez-Ávila ${ }^{1,2}$, Ben Castro ${ }^{1,3}$ and Juan J. Armesto ${ }^{1,3,4}$ \\ ${ }^{1}$ Instituto de Ecología y Biodiversidad, Santiago, Chile, ${ }^{2}$ Senda Darwin Biological Station, Ancud, Chile, ${ }^{3}$ Laboratorio \\ de Ecosistemas Terrestres, Departamento de Ciencias Biológicas, Pontificia Universidad Católica de Chile, Santiago, Chile, \\ ${ }^{4}$ Cary Institute of Ecosystem Studies, Millbrook, NY, United States
}

Rainfall partitioning in secondary forests from southern Chile is relevant in the climate change scenario, in which a $30 \%$ reduction in summer precipitation has been projected for the temperate region. Logging and degradation of old-growth forests has resulted in extensive secondary forests, over large areas of the Chiloé Archipelago as well as the mainland. These secondary forests are simple tree communities, dominated by two broad-leaved tree species, evergreen Drimys winteri and Nothofagus nitida, and have the potential to provide multiple benefits to society, including water provision, soil protection, and wood-derived products. Here, we ask how southern South American secondary rainforests modulate rainwater redistribution considering precipitation partitioning. We evaluated the seasonality of throughfall and stemflow components of precipitation, to assess ecohydrological processes for water regulation in a climate change context, where summer droughts have been more frequent in the last decade. The partitioning of gross rainfall (TP) into throughfall (TH), stemflow (ST), and canopy interception (IN) in relation to forest structure, was assessed in four forest plots (400 $\mathrm{m}^{2}$ each) in Senda Darwin Biological Station, Chiloé. TH and ST were measured seasonally for 35 rainfall events from 2019 to 2021. IN water losses were estimated from the mass balance equation. Results indicate that the secondary rainforest intercepts $33 \%$ of TP (990 mm of the total monitored), where $59 \%$ of the volume corresponds to $\mathrm{TH}$ and $7 \%$ to ST, which taken together account for nearly $100 \%$ the rainwater that reaches the forest floor. Canopy IN varied seasonally from 25 to $40 \%$ of total rainfall, with maximum values occurring in the growing season (spring-summer). We found no statistical relation between ST and forest structural parameters (DBH, Basal Area). We explored the contribution of the two dominant tree species to ST and discuss the results in a climate change context. Finally, we propose to incorporate this hydrologic knowledge into adaptive forest management strategies to maximize ecosystem benefits to people. If these ecosystems were properly managed, they have the potential to provide multiple benefits to society within this century, such as water provision and soil protection in addition to carbon sequestration in biomass.

Keywords: canopy interception, throughfall and stemflow, successional forests, seasonal rainfall, forest functions 


\section{INTRODUCTION}

Temperate rainforests of southern South America occur along the western land-ocean margin, with a mean distance to the ocean of $250 \mathrm{~km}$ between 37 and $55^{\circ} \mathrm{S}$ (Aravena et al., 2002; Astorga et al., 2018). South American temperate rainforests are under a strong oceanic influence, having high relative humidity and low temperature oscillation throughout the year. A strong climatic gradient is driven by the prevailing westerlies (from $<300 \mathrm{~mm} /$ year of rainfall east of the Andes to $>6,000 \mathrm{~mm} /$ year, in the coastal range to the west). The complex mountain topography results in dominance by broad-leaved evergreen, deciduous and mixed broad-leaf forest. Chilean temperate rainforests include a broad array of plant life forms, some of which are rare or lacking in other high-latitude forests (Aravena et al., 2002), such as numerous vines and epiphytes (e.g., vascular plants, bryophytes, lichens, ferns, and fungi). South American temperate forests differ from most of their counterparts from around the world, which in the northern hemisphere are overly dominated by conifers, cold-deciduous species, or a mixture of these (Gilliam, 2016).

Land-use change during the past two centuries in southcentral Chile has led to homogenization of forest structures and landscape patterns, through the massive loss of oldgrowth forests, which have been converted into degraded, secondary forests, pastures, and forestry plantations (Aravena et al., 2002; Armesto et al., 2010; Echeverría et al., 2012). Secondary forests as described here are geographically relevant ecosystems in southern Chile due to their broad distribution, accessibility, extensive natural regeneration, and high tree growth rates. Secondary forests reached at least one million hectares (Corporación Nacional Forestal [CONAF], and Universidad Austral de Chile [UACH], 2013) in the Lake District of southern Chile $\left(40.3-43.7^{\circ} \mathrm{S}\right)$, mainly dominated by trees in the genus Nothofagus. At least one fifth of the secondary forests surface is dominated by Drimys winteri and is concentrated mainly in Chiloé Archipelago (41.5-43.7 $\mathrm{S}$ ). In the meantime, forest fragmentation progresses by logging, fire, and clearance, with dramatic effects on the structure and composition of temperate forests (Armesto et al., 2010; Echeverría et al., 2012). Such changes in vegetation impact hydrological processes, such as rainfall partitioning that may itself affect the hydrological cycle and climate at continental and local scales (Sadeghi et al., 2020; Van Stan and Friesen, 2020; Yue et al., 2021). Important changes occur in catchment-scale water balances, evapotranspiration, and rainfall interception and distribution (Crockford and Richardson, 2000; Sadeghi et al., 2020; Van Stan and Friesen, 2020; Yue et al., 2021).

Climate change predictions differ markedly from the northern hemisphere (Intergovernmental Panel on Climate Change [IPCC], 2021). Increased droughts due to regional shifts in temperature and rainfall regimes are likely to affect South American temperate forests in the coming decades (Gutiérrez et al., 2014; Garreaud et al., 2017; Boisier et al., 2018). The period 2010-2020 has been characterized by reduced water supply in many areas of southern Chile (Garreaud et al., 2017; Boisier et al., 2018), presumably due to the synergistic effect of land use change, with subsequent loss of native forest cover, fragmentation, and degradation of ecosystems (Marquet et al., 2019). Climate models project a $25 \%$ decrease in annual precipitation for the temperate climatic zone (Fuenzalida et al., 2007; Boisier et al., 2018; Intergovernmental Panel on Climate Change [IPCC], 2021), which may mean up to 50\% less summer rain by 2100 (Gutiérrez et al., 2014; Intergovernmental Panel on Climate Change [IPCC], 2021).

In this context, precipitation partitioning by vegetation is a key process for water flow and storage in terrestrial vegetated ecosystems, since the interception of rainfall by plant canopies affects hydrologic processes, including related flows of materials and energy, and drives microclimate conditions, biodiversity, and ecosystem functions (Crockford and Richardson, 2000; Gutmann, 2020; Sadeghi et al., 2020; Van Stan and Friesen, 2020; Yue et al., 2021). Rainfall partitioning depends mainly on precipitation frequency and intensity, evaporation from the wet canopy and vegetation structure, but also from canopy gap sizes, air moisture, and water stored in the canopy at the beginning of each new rainfall event (Díaz et al., 2007; Gutmann, 2020; Van Stan and Friesen, 2020; Yue et al., 2021). Rainfall partitioning further depends on plant community structure characteristics, such as species composition, basal area, stem density, and leaf area and foliage type (Crockford and Richardson, 2000; Van Stan and Friesen, 2020; Yue et al., 2021).

To assess the consequences of forest dynamics on key ecosystem functions (e.g., water regulation) we need predictive tools that couple hydrologic processes, soil moisture dynamics, and plant productivity (Gutiérrez et al., 2014; Gutmann, 2020). In this context, hydrologic processes are important to understand the water flow paths through the ecosystems that dominate the landscape, which in several areas of southern Chile are driven by second-growth broad-leaved temperate forests. The partitioning of precipitation by vegetation into throughfall and evaporation can have large effects on water availability for both ecosystems and human consumption (Gutmann, 2020).

Few studies in southern Chile analyze rainfall partitioning in secondary and old-growth temperate forests, and they often have focused on local water balance at annual scale (Huber and Iroumé, 2001; Iroumé and Huber, 2002; Díaz et al., 2007; Oyarzún et al., 2011; Gutiérrez et al., 2014). Additionally, none of these studies have considered seasonal variation in rainfall and the consequences for forest dynamics. Rainfall partitioning in different seasons is important because the precipitation pattern changes each season, as well as the conditions that influence it, such as air temperature and humidity (Sadeghi et al., 2020; Yue et al., 2021). These add to the conditions related to climate change that foresees a decline summer rainfall within this century in southern South America (Fuenzalida et al., 2007; Boisier et al., 2018; Intergovernmental Panel on Climate Change [IPCC], 2021).

Our main objective here was to examine the temporal dynamics in rainfall partitioning across representative plots of a forest type that is important in southern Chile and predicted to be impacted by climate change. We aim to understand the relationship of seasonal rainfall partitioning with the composition and structure of second-growth rainforests 


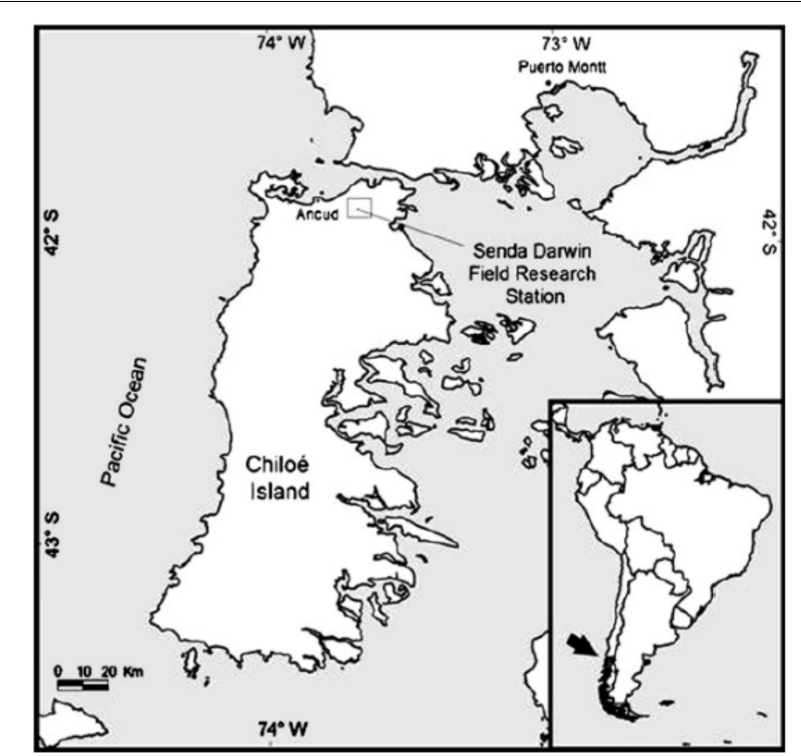

FIGURE 1 | Study site in Senda Darwin Biological Research Station, Chiloé Island, Southern South America, Chile.

dominated by Drimys winteri and Nothofagus nitida. We asked (i) How is rainfall redistributed seasonally in evergreen broadleaved secondary rainforests? and (ii) What species and tree sizes account additional water in summer?

Objective-based field studies like this not only collect needed regional information, but also enable us to strengthen current theory, if it is confirmed, to be broadly applicable across multiple systems. In this sense we hypothesize that, for the same amount of rain, there is a greater interception in summer than in winter. Also, we postulate the greater the magnitude of the rain event, the lower the percentage of interception, regardless of the season of the year. These affirmations are based on previous studies around the world (Sadeghi et al., 2020; Van Stan and Friesen, 2020; Yue et al., 2021). Moreover, in the climate change context, we expect to strengthen the current ecohydrological knowledge, where regulation of water balance must be an essential function for secondary forests that predominate in the landscape of southern Chile.

\section{MATERIALS AND METHODS}

\section{Study Area}

The study site is found in the Senda Darwin Biological Station, Ancud, in northern Chiloé Island ( $41^{\circ} 50^{\prime} \mathrm{S}, 73^{\circ} 40^{\prime} \mathrm{W}$, elevation $34 \mathrm{~m}$ a.s.l., Figure 1). According to Köppen and Geiger (1936), the climate is wet-temperate with strong oceanic influence (Di Castri and Hajek, 1976), with mean monthly temperatures ranging from 13.6 to $6.3^{\circ} \mathrm{C}$. Annual precipitation ranges from 2,000 to $2,500 \mathrm{~mm}$, of which $14 \%$ falls during the austral summer months (January-March; Díaz et al., 2007).

Soils in the study area developed in the last 14,000 years, over a geological basement made of unconsolidated sedimentary deposits, product of the interaction of factors such as volcanic activity, biological activity, climate, and glacial debris (Veit and Garleff, 1996; Hulton et al., 2002; Armesto et al., 2010). Study plots were located over fluvioglacial deposits and in depressions between relict moraine fields (Hulton et al., 2002; Díaz et al., 2007). Predominantly humid soils are known as nadis (Veit and Garleff, 1996; Centro de Información de Recursos Naturales [CIREN], 2002), corresponding to the Andosol order (Centro de Información de Recursos Naturales [CIREN], 2002). These soils possess a long water logging period and a shallow water table, especially during winter, due to the presence of an impermeable layer of iron and aluminum oxides, or hardpan (Centro de Información de Recursos Naturales [CIREN], 2002), which in these soils is found at an average of $52 \pm 3 \mathrm{~cm}$ below the surface (Díaz et al., 2007).

Secondary forests have homogeneous tree canopies dominated by one or a few pioneer tree species, trees of relatively small sizes (heights and stem diameters) that confer low stand volumes or biomass, scarce coarse woody debris and snags, and a low species diversity and understory density (Donoso, 1993; Ponce et al., 2017). Secondary rainforests are dominated by Drimys winteri and Nothofagus nitida, with occasional presence of Podocarpus nubigena, as a late successional species. The understory is composed mainly by Myrtaceae, Amomyrtus meli, A. luma, and Tepualia stipularis, shaded by a dominant 28-m tall canopy (Díaz et al., 2007). The basal area was $76 \pm 16 \mathrm{~m}^{2} /$ ha (Table 1 ).

\section{Methodology}

The partitioning of gross rainfall (TP) into throughfall (TH), stemflow (ST), and interception loss (IN) and their relationships with forest structure were studied for a period of 2 years, within four $400 \mathrm{~m}^{2}$ secondary rainforest plots (Table $\mathbf{1}$ ).

A rainfall event is defined in this study as the precipitation that falls in a time interval, which can be separated by at least $12 \mathrm{~h}$ from a previous or subsequent rainfall event. Incident precipitation (TP) was assessed with a Campbell (Logan, UT, United States) meteorological station located within Senda Darwin Biological Station (approximately $100 \mathrm{~m}$ from the study plots). The rain gauge had a resolution of $0.25 \mathrm{~mm}$ and provided information about the date, duration, and volume of individual rainfall events.

In each plot, $\mathrm{TH}$ was estimated using a net of six polypropylene collectors of 2,400 $\mathrm{cm}^{2}$ at $1 \mathrm{~m}$ aboveground, randomly assigned inside the forest plots. As these gutters had a length of $1 \mathrm{~m}$, each collector received rainwater from a variety of representative situations, from canopy gaps in forest to full cover of tree canopy. ST was assessed in 10 target trees with stemflow collectors located between 1.3 and $1.4 \mathrm{~m}$ height on the trees. Stemflow collectors consisted of an acrylic funnel that surrounds the trunk. Each collector was connected to a hose with a 23liter polypropylene container, installed in the forest floor. Overall, trees selected for the study ranged from 11.6 to $30.5 \mathrm{~cm}$ diameter at breast height, representing the tree diameter distribution in this rainforest (Table 1).

Throughfall and stemflow was measured for 35 single rainfall events in 22 months (Table 1), distributed between April 2019 
TABLE 1 | Forest attributes per plot in second-growth forests of Chiloé.

\begin{tabular}{|c|c|c|c|c|c|}
\hline Basal area $\left(\mathrm{m}^{2} / \mathrm{ha}\right)$ & Plot A & Plot B & Plot C & Plot D & Average \\
\hline Drimys winteri & 37 & 31 & 37 & 47 & 38 \\
\hline Nothofagus nitida & 16 & 29 & 31 & 37 & 28 \\
\hline Others spp. & 8 & 9 & 12 & 13 & 11 \\
\hline Total & 61 & 69 & 81 & 97 & 77 \\
\hline \multicolumn{6}{|l|}{ N. of individuals (/ha) } \\
\hline Drimys winteri & 1,500 & 1,225 & 1,775 & 1,500 & 1,500 \\
\hline Nothofagus nitida & 550 & 875 & 1,600 & 1,325 & 1,088 \\
\hline Others spp & 1,125 & 1,300 & 1,150 & 925 & 1,125 \\
\hline Total & 3,175 & 3,400 & 4,525 & 3,750 & 3,713 \\
\hline \multicolumn{6}{|c|}{ Average diameter $(\mathrm{cm})$} \\
\hline Drimys winteri & 16.3 & 16.7 & 14.7 & 18.6 & 16.6 \\
\hline Nothofagus nitida & 17.8 & 18.3 & 14.5 & 17.9 & 17.1 \\
\hline \multicolumn{6}{|c|}{ Precipitation partitioning } \\
\hline Throughfall (\%) & $62 \%$ & $69 \%$ & $52 \%$ & $55 \%$ & $59 \%$ \\
\hline Stemflow (\%) & $6 \%$ & $3 \%$ & $8 \%$ & $12 \%$ & $7 \%$ \\
\hline Interception (\%) & $33 \%$ & $28 \%$ & $40 \%$ & $33 \%$ & $33 \%$ \\
\hline
\end{tabular}

and January 2021. Interception losses were calculated from Huber and Iroumé (2001) equation:

$$
I N=T P-(T H+S T)
$$

Where IN is the evaporation of intercepted precipitation, TP is the total precipitation at open field, $\mathrm{TH}$ comprises rainfall reaching the forest floor in a direct way not touching the vegetation and canopy drip, and ST correspond to the rainwater that flows along the stems or tree trunks to the forest floor.

To estimate IN, TP was transformed from millimeters (rain gauge measurement) to total liters received in each plot. To obtain ST in each plot (per unit ground area) by rain event, we used the mean stemflow yield extrapolation method (Levia and Germer, 2015; González-Martínez et al., 2017), where total liters collected by individual trees in each event, were extrapolated to plot scale with the basal areas of both targeted trees and plot (González-Martínez et al., 2017).

Events were grouped according to seasonality. Rain events sampled for autumn-winter season were 15 events with magnitude between 3.5 and $63.9 \mathrm{~mm}$, (1-8 days in length, mean $=3.5$ ) while in the spring-summer season, we measured 20 events with magnitudes ranging between 7.4 and $76.5 \mathrm{~mm}$ (1-10 days in length, mean $=4.4)$.

The importance of seasons was analyzed through the statistic two-way ANOVA, considering plots (4) and seasonality (2) as factors. Finally, the relationship of IN and ST respect to basal area and tree sizes $(\mathrm{DBH})$, respectively, were analyzed. The $\mathrm{DBH}$ of all trees in each plot was measured with a caliper and the basal area was estimated with the sum per unit area of all the stems at the DBH level.

\section{RESULTS}

For the monitored rainfall events there was a positive relationship between the volume and intensity of precipitation, and this trend was stronger in the autumn-winter season (Supplementary Figure 1).

The rainfall partitioning for the study period indicates a fourplot mean $( \pm S D)$ of $33 \pm 5 \%$ canopy interception of total rainfall, while the rain that passed through the canopy was $59 \pm 8 \%$ and stemflow reached $7 \pm 4 \%$ of the total rainfall sampled (Table 1 ). When separating the events according to seasons of the year, throughfall and stemflow varied between seasons, with a mean of $67 \pm 0.07 \%$ of TH and $8.5 \pm 0.04 \%$ of ST in the autumn-winter period, and $53 \pm 0.08 \%$ of TH and $6 \pm 0.04 \%$ of ST for springsummer, with respect to the total rain events sampled in this study (Table 2). Then, mean IN for the four plots increased from $24 \pm 0.04 \%$ in autumn-winter to $40 \pm 0.06 \%$ in spring-summer period (Table 2). When observing these results by study plots, $\mathrm{TH}$ and ST decreased in spring-summer in all plots compared with the autumn-winter period (Table 2).

The relationship between rainfall volume and $\mathrm{TH}$ was positive in both seasons (Supplementary Figure 2A), while when the volume of precipitation increased IN decreased (Supplementary Figure 2B). This trend was slightly stronger in spring-summer period. Stemflow showed no relationship with rainfall volume in spring-summer season, but an inverse relationship in autumnwinter season (Supplementary Figure 2B).

When season and plot factors were analyzed, there was no significative interaction. Despite a trend of IN increment as the stand basal area increased (Table 1), IN varied significantly between seasons, with spring-summer higher interaction ( $p=1.05 \mathrm{E}-09$ ) than the autumn-winter period (Figure 2).

Stemflow during the study period accounted 5,820 liters of water accumulated for D. winteri and 5,679 liters for $N$. nitida for $N=35$ rain events measured. Considering the spring-summer rain events, we observed that $D$. winteri accumulated a slightly greater amount of stemflow water, with values that exceeded 2,900 liters, compared to N. nitida which barely exceeded 2,800 liters. However, we found no statistical differences between means in both species for spring-summer stemflow accumulation 
TABLE 2 | Rainfall partitioning (\%) by season of the year and by plot.

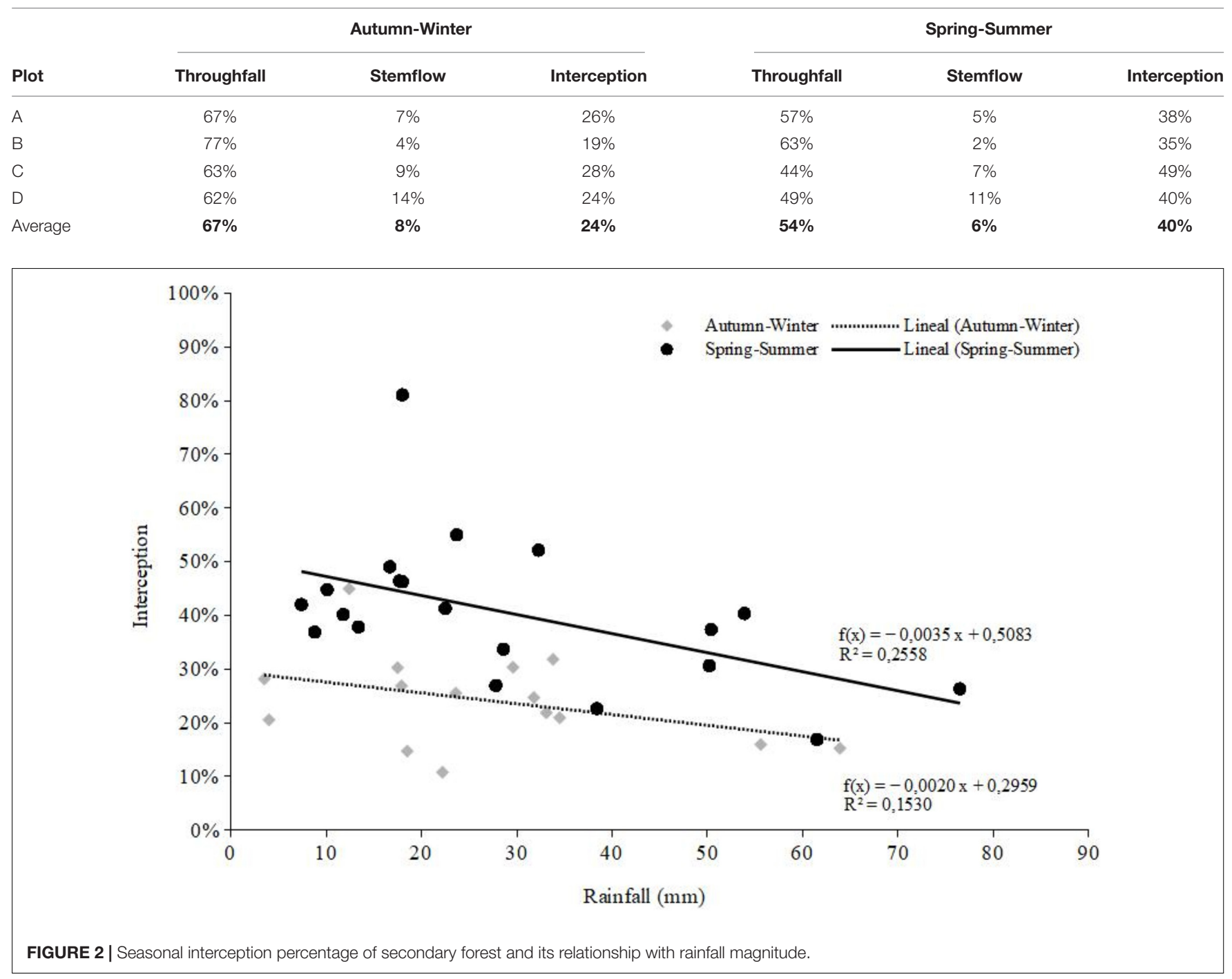

(M-W, $z=0.46, p=0.64)$. We observed that stemflow increased in both species according to trees sizes, however, the slope of the curve for D. winteri was steeper (Figure 3).

\section{DISCUSSION}

Our results contribute to understanding the hydrological processes in widely distributed secondary rainforests generated after logging in the temperate zone of South America. Our main result, that had not been previously reported in Chile, is the seasonal analysis showing greater interception of rainfall in the spring-summer season, compared with similar rain events in autumn-winter (Figure 2). This result can be explained by the meteorological conditions of each period, since during springsummer season there is a higher average temperature and lower relative air moisture, which together facilitates evaporation from the forest canopy; on the other hand, in autumn-winter the air relative humidity is higher, and the temperature is lower
(Crockford and Richardson, 2000; Sadeghi et al., 2020; Yue et al., 2021).

The results obtained allow us to affirm that the objectives raised are fulfilled, since we assessed the temporal dynamics in rainfall partitioning across secondary rainforests, with greater interception in the spring-summer period (Figure 2). Also, regardless of the season of the year, the interception decreases as the volume of rainfall per event increases (Figure 2 and Supplementary Figures 1B, 2).

Previous studies in Chilean temperate forest evaluated precipitation partitioning annually, and the general results of rainfall redistribution from our study $(\mathrm{TH}, \mathrm{ST}$, and IN for the entire period studied) indicate that these secondary rainforests have a different hydrologic response compared to other forest types. In Andean old-growth temperate forests, with $4,000 \mathrm{~mm}$ of rainfall and with a mixture of deciduous and evergreen species, direct precipitation reaches $79 \%$ and stemflow 7\%, with an overall interception of 14\% (Iroumé and Huber, 2002). The main difference with our results is the 


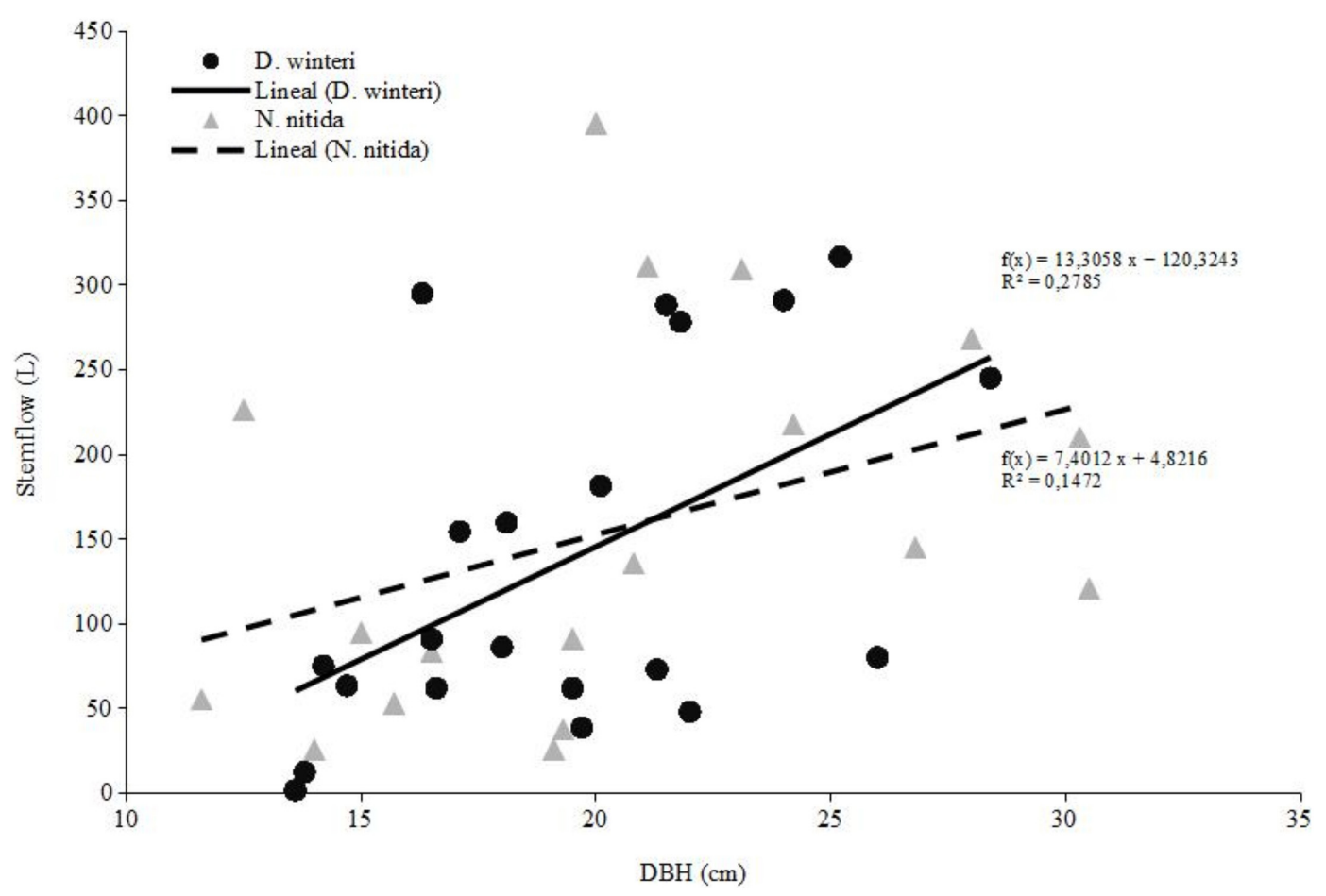

FIGURE 3 | Total spring-summer stemflow of dominant species.

lower proportion of water interception, which can be explained by the abundance of deciduous species in these old-growth temperate rainforests and the rainfall characteristics in the Andean Mountain range (on temperate zones), which in general have greater intensity and duration. Note this old-growth forests are different from the ones studied in this research, which corresponds to secondary rainforests.

In Andean old-growth temperate rainforests dominated by broadleaved evergreen species, with high annual rainfall amounts $(5,000 \mathrm{~mm})$, the values for direct precipitation $(\mathrm{TH})$ oscillate between 64 and 89\%, while ST ranged between 0.3 and 3.4\% (Oyarzún et al., 2011), with IN ranging between 11 and 36\% of the total rainfall. The main difference with our results is a lower proportion of stemflow, which can be explained by the attributes of tree species of this old-growth rainforests, such as the dense epiphytic vegetation cover (vascular plants, bryophytes, lichens, ferns, and fungi) on the trunks, plus the bark roughness and the largest stem diameters. On the other hand, in coastal zones with analogous precipitation volumes reaching $2,500 \mathrm{~mm}$ annually, broadleaved evergreen rainforests showed similar results, with $\mathrm{TH}$ ranges between 60 and 74\% while stemflow varies between 1 and $7 \%$, with interception ranging between 22 and $37 \%$ (Huber and Iroumé, 2001).

An annual study in secondary evergreen broadleaf rainforests in the Chiloé Archipelago showed a canopy interception of 31\% and a net precipitation (TH + ST) of 67\% (Díaz et al., 2007). These values are quite similar to those obtained in this study, but only at a general level, since there was no seasonal analysis of these results. This can be explained by the similarity between the forests studied and their climate, since the area from both studies were close and share the same species.

All these studies indicate a high variability of hydrologic responses according to climate conditions, forest compositions and successional stage. This reinforces the idea that we need a better understanding of forest responses to precipitation changes at local scale, which can provide fundamental information for conservation and management under changing climatic regimes.

A comparison with forests at global scale, across different climate types, showed that the median relative throughfall varied from $70 \%$ in temperate and boreal sites to $80 \%$ in the tropics (Sadeghi et al., 2020). Our results are consistent with those obtained in other temperate forests of the world, particularly temperate rainforest (Yue et al., 2021).

Overall, studies of global patterns and drivers of rainfall partitioning showed that plant traits were key predictors of relative stemflow, and plant traits and meteorological factors were key predictors of relative interception and throughfall (Yue et al., 2021). In general, local-scale levels of interception under small and low-intensity rainfall events are greater in plants with larger and more dense canopies, resulting in lower levels of throughfall and stemflow (Gutmann, 2020; Yue et al., 2021). The number of tree branches, their insertion angle, leaf number, and stem basal diameter influenced stemflow yield (Sadeghi et al., 2020; Yue et al., 2021). On the other hand, under large and high-intensity rainfall events, water capture is greater in large plants with less dense canopies, resulting in higher stemflow proportion (Yue et al., 2021). In our study, we observed a similar trend for IN (Figure 2), when the volume and intensity of rainfall increases, 
and stemflow is enhanced by the greater stem DBH of both $D$. winteri and N. nitida (Figure 3). In summary, this research addressed the main forcing factors of rainfall redistribution inside second-growth temperate rainforests, but we recognize that other factors not considered here may have influenced these results, since we are studying complex forest systems. Climate variables such as air moisture and temperature, and species attributes such as bark roughness, branch numbers, insertion angles, and leaf area index, could improve our understanding of this forest ecosystem.

Considering the anomalies predicted for the second half of the present century by climate change models (Garreaud et al., 2017; Boisier et al., 2018; Intergovernmental Panel on Climate Change [IPCC], 2021), temperatures are expected to increase and summer precipitation to decrease, with more frequent extreme events. So, fewer but more intense rain events could be expected in summer, with an overall lower volume of total rainfall.

Summer rainfall data showed a decline in Chiloé Island (Supplementary Figure 3) in the last two decades, which indicates that the changes projected by climate models could occur earlier than expected, with relevant consequences for forest hydrology. Therefore, we expect a lower forest interception of individual rain events, which means enhanced infiltrating water into the forest soil, but, in absolute terms, there will be less water available for the spring-summer period.

Concerning forest management, net precipitation (sum of throughfall and stemflow) can be seen as the water that the forest "collects and stores" for ecosystem processes, and interception is considered water lost by evaporation. Current management guidelines for secondary rainforests dominated by $D$. winteri and $N$. nitida focus primarily on timber production (Donoso et al., 2007; Navarro et al., 2011; Salas-Eljatib et al., 2019). Considering the results from this study, an alternative management strategy could be implemented in order to allow multiple uses of forests. In this sense, the analysis of the hydrologic responses of the dominant tree species are relevant, since in the spring-summer season $D$. winteri has a greater stemflow than N. nitida, as stem diameter increases (Figure 3). This result can contribute to the future management of secondary rainforests, because under climate change projections it is desirable to reduce the interception of summer rain by forest canopy, to take advantage of the lower precipitation volumes expected by climatic change predictions.

Future assays may be directed to manage secondary rainforests at different basal areas and canopy covers of trees, to evaluate water infiltration rates into the forest floor, without affecting

\section{REFERENCES}

Aravena, J., Carmona, M., Perez, C., and Armesto, J. J. (2002). Changes in tree species richness, stand structure and soil properties in a successional chronosequence in northern Chiloe Island, Chile. Rev. Chilena Historia Nat. 75, 339-360.

Armesto, J. J., Manuschevich, D., Mora, A., Smith-Ramirez, C., Rozzi, R., Abarzua, A., et al. (2010). From the Holocene to the Anthropocene: a historical framework for land cover change in southwestern South America in the past other ecological functions (e.g., soil protection), particularly in aquifer recharge areas, watershed headwaters, and areas that are sources of water provision for human use. Then, changes in water regulation can be evaluated through logging practices, such as reduction of forest density through thinning of the smaller diameter classes, or by reducing leaf area through pruning, which would decrease both interception and transpiration from trees, consequently allowing a greater soil water storage in the forest ecosystem.

In synthesis, if these ecosystems are properly managed, they have the potential to provide multiple benefits to society within this century, such as wood, greater water provision, carbon sequestration and soil protection, while preserving multiple components of the local biodiversity.

\section{DATA AVAILABILITY STATEMENT}

The raw data supporting the conclusions of this article will be made available by the authors, without undue reservation.

\section{AUTHOR CONTRIBUTIONS}

$\mathrm{CF}, \mathrm{MN}-\overline{\mathrm{A}}$, and JA contributed to the conception and design of the study. MN-Á, BC, and CF participated in fieldwork and analyzed the data. $\mathrm{MN}-\hat{A}$ and $\mathrm{BC}$ participated in data collection and performed the statistical analysis. $\mathrm{BC}$ organized the database. CF wrote the first draft of the manuscript. All authors contributed to manuscript revision, read, and approved the submitted version.

\section{FUNDING}

We acknowledge the support of the Institute of Ecology and Biodiversity (IEB-Chile), through grants AFB170008 and ACE210006 from ANID-Chile, and logistics facilities provided by the Senda Darwin Biological Station, LTSER-Chile site.

\section{SUPPLEMENTARY MATERIAL}

The Supplementary Material for this article can be found online at: https://www.frontiersin.org/articles/10.3389/ffgc.2021. 781663/full\#supplementary-material

15,000 years. Land Use Policy 27, 148-160. doi: 10.1016/j.landusepol.2009.07. 006

Astorga, A., Moreno, P., and Reid, B. (2018). Watersheds and trees fall together: an analysis of intact forested watersheds in southern Patagonia (41-56 $6^{\circ}$ ). Forests 9:385. doi: 10.3390/f9070385

Boisier, J., Alvarez-Garretón, C., Cordero, R., Damiani, A., Gallardo, L., Garreaud, R., et al. (2018). Anthropogenic drying in central-southern Chile evidenced by long-term observations and climate model simulations. Elementa Sci. Anthropocene 6:74. 
Centro de Información de Recursos Naturales [CIREN] (2002). Estudio Agrológico $X$ Región, Descripciones de suelos Materiales y Símbolos. Santiago: CIREN.

Corporación Nacional Forestal [CONAF], and Universidad Austral de Chile [UACH] (2013). Informe Final de Monitoreo de cambios, corrección Cartográfica y Actualización del Catastro de Recursos Vegetacionales Nativos de la Región de Los Lagos. Valdivia: CONAF.

Crockford, R., and Richardson, D. (2000). Partitioning of rainfall into throughfall, stemflow and interception: effect of forest type, ground cover and climate. Hydrol. Proc. 14, 2903-2920. doi: 10.1002/1099-1085(200011/12)14: 16/17<2903::aid-hyp126>3.0.co;2-6

Di Castri, F., and Hajek, E. (1976). Bioclimatología de Chile. Santiago: Editorial P. Universidad Católica de Chile.

Díaz, M., Bigelow, S., and Armesto, J. J. (2007). Alteration of hydrologic cycle due to forest clearing and its consequences for rainforest succession. Forest Ecol. Manag. 244, 32-40. doi: 10.1016/j.foreco.2007.03.030

Donoso, C. (1993). Bosques Templados de Chile y Argentina: Variación Estructura $y$ Dinámica. Santiago: Editorial Univeristaria S.A.

Donoso, P., Soto, D., and Bertin, R. (2007). Size-density relationships in Drimys winteri secondary forests of the Chiloe Island, Chile: effects of physiography and species composition. Forest Ecol. Manag. 239, 120-127. doi: 10.1016/j.foreco. 2006.11.015

Echeverría, C., Newton, A., Nahuelhual, L., Coomes, D., and Rey-Benayas, J. (2012). How landscapes change: integration of spatial patterns and human processes in temperate landscapes of southern Chile. Appl. Geography 32, 822-831. doi: 10.1016/j.apgeog.2011.08.014

Fuenzalida, H., Aceituno, P., Falvey, M., Garreaud, R., Rojas, M., and Sanchez, R. (2007). Study on Climate Variability for Chile During the 21st Century. Santiago: CONAMA, Ministerio del Medio Ambiente.

Garreaud, R., Alvarez-Garreton, C., Barichivich, J., Boisier, J., Christie, D., Galleguillos, M., et al. (2017). The 2010-2015 megadrought in central Chile: impacts on regional hydroclimate and vegetation. Hydrol. Earth System Sci. 21, 6307-6327. doi: 10.5194/hess-21-6307-2017

Gilliam, F. (2016). Forest ecosystems of temperate climatic regions: from ancient use to climate change. New Phytol. 212, 871-887. doi: 10.1111/nph.14255

González-Martínez, T., Williams-Linera, G., and Holwerda, F. (2017). Understory and small trees contribute importantly to stemflow of a lower montane cloud forest. Hydrol. Proc. 31, 1174-1183. doi: 10.1002/hyp.11114

Gutiérrez, A., Armesto, J., Díaz, M., and Huth, A. (2014). Increased drought impacts on temperate rainforests from southern south america: results of a process-based. dynamic forest model. PLoS One 9:e103226. doi: 10.1371/ journal.pone. 0103226

Gutmann, E. (2020). "Global modeling of precipitation partitioning by vegetation and their applications," in Precipitation Partitioning by Vegetation, A Global Synthesis, eds J. Van Stan, E. Gutmann, and J. Friesen (Switzerland: Springer Nature).

Huber, A., and Iroumé, A. (2001). Variability of annual rainfall partitioning for different sites and forest covers in Chile. J. Hydrol. 248, 78-92. doi: 10.1016/ s0022-1694(01)00394-8

Hulton, N., Purves, R., McCulloch, R., Sugden, D., and Bentley, M. (2002). The last glacial maximum and deglaciation in Southern South America. Quaternary Sci. Res. 21, 233-241. doi: 10.1016/s0277-3791(01)00103-2

Intergovernmental Panel on Climate Change [IPCC] (2021). "Climate change 2021: the physical science basis," in Contribution of Working Group I to the Sixth Assessment Report of the Intergovernmental Panel on Climate Change, eds V. Masson-Delmotte, P. Zhai, A. Pirani, S. L. Connors, C. Péan, S. Berger, et al. (Cambridge: Cambridge University Press). doi: 10.1007/s10584-02103233-7
Iroumé, A., and Huber, A. (2002). Comparison of interception losses in a broadleaved native forest and a Pseudotsuga menziesii (Douglas fir) plantation in the Andes Mountains of southern Chile. Hydrol. Proc. 16, 2347-2361.

Köppen, W., and Geiger, R. (1936). Handbuch der Klimatologie. Berlin: Gebrueder Borntraeger.

Levia, D., and Germer, S. (2015). A review of stemflow generation dynamics and stemflow-environment interactions in forests and shrublands. Rev. Geophys. 53, 673-714.

Marquet, P., Lara, A., Altamirano, A., Alaniz, A., Álvarez, C., Castillo, M., et al. (2019). Cambio de Uso del Suelo en Chile: Oportunidades de Mitigación ante la Emergencia Climática. Informe de la mesa Biodiversidad. Santiago: Comité Científico COP25; Ministerio de Ciencia, Tecnología, Conocimiento e Innovación.

Navarro, C., Herrera, M., Drake, F., and Donoso, P. (2011). Diagrama de manejo de densidad y su aplicación a raleo en bosques de segundo crecimiento de Drimys winteri en el sur de Chile. Bosque 32, 175-186. doi: 10.4067/s071792002011000200008

Oyarzún, C., Godoy, R., Staelens, J., Donoso, P., and Verhoest, N. (2011). Seasonal and annual throughfall and stemflow in Andean temperate rainforests. Hydrol. Proc. 25, 623-633. doi: 10.1002/hyp.7850

Ponce, D., Donoso, P., and Salas-Eljatib, C. (2017). Differentiating structural and compositional attributes across successional stages in chilean temperate rainforests. Forests 8:329. doi: 10.3390/f8090329

Sadeghi, S., Gordon, D., and Van Stan, I. I. (2020). “A global synthesis of throughfall and stemflow hydrometeorology," in Precipitation Partitioning by Vegetation, A Global Synthesis, eds J. Van Stan, E. Gutmann, and J. Friesen (Switzerland: Springer Nature).

Salas-Eljatib, C., Corvalán, P., Pino, N., Donoso, P., and Soto, D. (2019). Modelos de efectos mixtos de altura-diámetro para Drimys winteri en el sur (41-43 $\left.{ }^{\circ} \mathrm{S}\right)$ de Chile. Bosque 40, 71-80. doi: 10.4067/s0717-92002019000100071

Van Stan, J., and Friesen, J. (2020). "Precipitation partitioning, or to the surface and back again: historical overview of the first process in the terrestrial hydrologic pathway," in Precipitation Partitioning by Vegetation, A Global Synthesis, eds J. Van Stan, E. Gutmann, and J. Friesen (Switzerland: Springer Nature).

Veit, H., and Garleff, K. (1996). "Evolución del paisaje cuaternario y los suelos en Chile central-sur," in Ecología de los Bosques Nativos de Chile, eds J. J. Armesto, C. Villagran, and M. T. K. Arroyo (Santiago: Editorial Universitaria).

Yue, K., De Frenne, P., Fornara, D., Van Meerbeek, K., Li, W., Peng, X., et al. (2021). Global patterns and drivers of rainfall partitioning by trees and shrubs. Global Change Biol. 27, 1-8. doi: 10.1111/gcb.15644

Conflict of Interest: The authors declare that the research was conducted in the absence of any commercial or financial relationships that could be construed as a potential conflict of interest.

Publisher's Note: All claims expressed in this article are solely those of the authors and do not necessarily represent those of their affiliated organizations, or those of the publisher, the editors and the reviewers. Any product that may be evaluated in this article, or claim that may be made by its manufacturer, is not guaranteed or endorsed by the publisher.

Copyright (C) 2022 Frêne, Núñez-Ávila, Castro and Armesto. This is an open-access article distributed under the terms of the Creative Commons Attribution License (CC BY). The use, distribution or reproduction in other forums is permitted, provided the original author(s) and the copyright owner(s) are credited and that the original publication in this journal is cited, in accordance with accepted academic practice. No use, distribution or reproduction is permitted which does not comply with these terms. 